\title{
Life After Amputation: A Case Study
}

\author{
Raul V. San Diego \\ Adventist University of the Philippines \\ rvsandiego@aup.edu.ph
}

\begin{abstract}
In the Philippines, the National Council on Disability made a survey revealing a prevalence of 43.367 disabled who lost one or both legs and/or feet. This study explored the challenges encountered and coping mechanisms an amputee manifests, and the assistance that they get from their expected support system. This case study was anchored on Dorothea Orem's SelfCare Theory of Nursing. Four purposively sampled amputee informants were interviewed and observed. Primary and secondary data were gathered and triangulation with the relatives was done to ensure the validity and depth of the results. Data were encoded and analyzed using thematic analysis. Results revealed that the informants experienced physical, psychological, emotional, socio-economic, and spiritual challenges. Physical challenges involved mobility problem and lack of gait balance, physical deformity, adjustment to the new body, altered physical appearance, a sedentary behavior, and phantom pain. Psychological challenges involved suicidal tendency, loss of libido, self-pity, and depression. Emotional challenges included fear and hopelessness. Socio-economic challenges involved the development of antisocial behavior, dissociative behavior, fear of losing a job, problem with money, and fear of rejection. Spiritual challenges involved loss of faith. Coping mechanism included support from family and friends, mastery of gait and balance, proper practice in using assistive devices, hastened adjustment to the new body, wearing of prosthesis, medication and mobility, and trust in God. Although they get strong support from the family and friends, there is very limited assistance from the government and the community. There is a need to increase family awareness in anticipating the needs of the amputees. Likewise, full support must be given to them. Health education campaign may be formulated by the local health leaders and provision of assistive devices and equipment to achieve the equalization and opportunities for persons with disabilities may also be done.
\end{abstract}

Keywords: Life After Amputation, Amputation Case Study, Amputee Life Challenges

\section{INTRODUCTION}

Lower limbs are used for standing, walking, running, jumping, kicking, and similar activities. Lots of people across the globe are losing their lower limb resulting to amputation. Incidence rates of acquired amputations vary greatly between and within countries. In Japan, it ranges from 1.2 per 10000 women to 4.4 per 10000 men in the Navajo nation in the USA (Burger \& Marincek, 2007). In the United States, there are approximately 1.7 million people living with 
limb loss. It is estimated that one out of every 200 people in the U.S. has had an amputation (Graham, 2008).

In the Philippines, National council on disability made a survey in the year 2000 revealing prevalence of 43, 367 disabled in the Philippines who lost one or both legs and or feet. It was categorized to different age group from under 1 year old to 80 years old and over. The national capital region had a total of 4,284, in which 2,576 amputees are males and 1,708 are females. For the rest of the twelve regions in the Philippines including the Cordillera Administrative Region, Autonomous Region of Muslim Mindanao and the CARAGA administrative region it was totaled to 24,671 males and 14,412 amputated females recorded (National council on Disability Affairs [NCDA], 2013).

Amputation itself is a change in body structure, but has a great influence on many activities, participation in activities and quality of life. Lower limb injuries can lead to considerable disability and dependency in later life. Amputation could be caused by a trauma, cancer related amputation, congenital related incidences or it may be due to diabetic neuropathy or peripheral vascular disease (Santy, 2009). The World Health Organization (WHO) calls attention to this problem that lower limb amputations are increasing and states that more than half of these lower limb amputations could be prevented with adequate detection and care (Day, 2011).

People who experienced amputation face great physical challenges and followed by emotional, mental, social and even the spiritual aspect of their life that need change. It is a new start or a new beginning on how they will accept the life they live in. For a negative response amputee verbalized reactions and feelings such as sadness, shock, insurgence, surprised, nonacceptation of the situation, anger and suicidal thoughts. Including fear of losing the remaining limb and fear of losing their life after all the challenges they are experiencing were also common (Senra Hugo, 2011).

This case study was intended to provide knowledge about the life situation of patients who had undergone lower limb amputation as a basis for future development of nursing rehabilitation program to increase the quality of life of an amputee.

This case study focused in the life experiences, challenges in life, and health seeking behavior of four amputees who had undergone lower extremity amputation for over a six-month postoperative duration. The study involved the review of the patient's medical profile from the hospital records. To dig more information, interview with the participants was undertaken using unstructured questions and observation. 
Thus, the researcher is challenged to conduct the study: To know the life situation of a patient that had undergone lower limb amputation. To seek the different life challenges encountered and the health seeking behavior an amputee manifest. It is also the researcher's goal to be the portal in identifying what to be recommended on how to improve life after amputation..

\section{LITERATURE REVIEW}

The substantial data provided give support and evidence to the present case study about life after amputation among individuals with lower limb amputation.

As cited by Finkel (2011), and O'Reilly (2011) showing the same findings that the complexity of health in life after amputation were like disability because it embodied the whole aspect of life and not merely the absence of disease. Amputees meet a lot of challenges in their whole life especially after surgery or losing their limb and problems arise from different aspects of their life.

Like the present study the researcher compared the different life challenges experienced among amputee. The different challenges faced by the informants to elaborate are: Physical challenges, psychological challenges, emotional challenges, social challenges, and spiritual challenges. Physical challenge for the amputee is the utmost ordeal of their life.

As Dyer and Ostwald (2012), Fitzsimmons (2011), Gondo (2012), and Hamilton (2012) discuss the similarities in their studies about the activities of daily living as the basic and essential routine of an individual for everyday life. It is like the recent study that informants live experiences determine the significance of their ability to perform task and the ability to cope with their immobility problem. Amputee shows independence but not all. Adjustment and balance of their new body and proper education about care are essential to the amputee.

An old saying "Pain is a Friend" but not to the amputee. Pain should have boundary or limit. Bosmans, geertzen, Post, Van der Schans, and Dijkstra (2010) and Perrin, Sheenan, and POtter (2012) had different study about phantom pain that yielded the same result that pain needs immediate attention to deal with and alleviate. Unlike the phantom pain, which is felt by the amputee, but the location of pain is vague. This also needs attention because the pain could be intense, and it is common though pain reduce with time. This present study in comparison with the informants experienced phantom pain though it is common but not all informants experienced it. The nature of pain is the same as the other amputee experienced phantom limb pain. 
According to Senra Hugo (2011) almost a decade where ten studies have been carried out on the experience of limb amputation only two of these addressed the self-identity changes related to limb loss This study focus on self-identity and self-efficacy which underlies the concept of the psychological challenge brought about by amputation. This present case study about life after lower limb amputation will be the first study focus on the quality of life among lower limb amputee here in the Philippines. This case study does not focus merely to self-identity changes and self-efficacy but the whole concept of self that patient experience after lower limb amputation. The ability to function independently without outside control can contribute to each identity where self-reliant is developed and progress to form a self-concept.

In the study of Donatelle (2012) found out that family relationships as a couple or being single contribute to each member of the family social involvement. The amputee's association to his or her family even the adjustment and adaptability can be predicted through his or her upbringing or family background in the home environment according to the study. In comparison the present study showed that healthy nurturing environment has a significant role in one's relationship. For married and non-married couples' studies show that being an amputee is no longer a cause of rejection. A healthy relationship could contribute to a better quality of life. Self-involvement is the only key for a better life. No more loneliness, no more isolation, sickness and depression. People with disability nowadays are welcomed by the society. Also, the involvement of the amputee to the community is a sign of functioning. This recent study shows that amputees' families had a great influence on the coping process of patient undergone lower limb amputation. The support given by the family helped therapeutically the individual with amputation.

According to Gondo (2013) emotional well-being plays an important role in their daily lives. Study showed that to kill sad emotion and depression amputee should learn how to involve self to any activity. The present study showed that the emotional well-being of the amputee become low during the first few months after amputation. With the help of the family and other social group it helps amputee recover from anxiety and depression.

Donatelle (2012) believed that spirituality is an element that is difficult to describe which it gives purpose to human being to live by. A person without any affiliation to any religious group has a need for this Supreme Being and to some that is connected or belongs to any beliefs they call their God as "Allah", to some "Yahweh", or "Buddha", for the Christian's Lord God the Father the Son and the Holy Ghost. To whatever beliefs a person has, it will arise the consciousness of an amputee to meet the challenges and the coping skills for whatever 
challenges they will face in their future. According to Cordova (2011) believe that the patient's quality of life improves once they experience the indescribable achievement spirituality gives. Once positive outlook is achieved fulfillment of goals will serve as a driving force to become achiever. The physical, social, psychological and spiritual will change over this time and there is wholeness for the amputee. The quality of life of an amputee will improve and change, ready for the challenges that he or she will face.

In this present study spirituality is explained by the informants as a powerful tool in coping with disability. It is like the study of Cordova (2011) that once amputee had reached the ultimate life experiences spirituality gives hope through believing with the existence of the indescribable uplifting feeling of the spirit.

This study showed the different life experiences of lower limb amputee, expressed how amputee faced the problems as challenges and study what is their concept in life after amputation.

\section{METHODS}

\section{Research Design}

This case study determined the lived experiences of four lower limb amputees and specifically used qualitative case study research design. Yin (2009) discussed that case study as in-depth examinations of people or groups of people. A case study could also examine an institution, such as hospice care for the dying. In medicine, case studies have frequently been concerned with a disease (Teddlie \& tashakkori, 2009). In nursing, the case study approach is used to explore the in-depth pathophysiology of a certain disease and that includes the nursing objective and intervention of nursing care fitted to patient. Content analysis is used in evaluating the data from case studies (Yin, 2009). Creswell (2009) stated that understanding the lived experiences marks as a philosophy as well as a method, and the procedure involves studying a small number of subjects through extensive and prolonged engagement to develop patterns and relationships of meaning. In this process, the researcher brackets or sets aside his own experiences in order to understand those of the participants in the study.

\section{Informants of the Study}

The informants of the case study were the four participants who had undergone lower limb amputation among hospitals in Lipa City, Batangas over a six months post-operative duration in the year $2009-2013$. 
Informant \# 1 is a 24 years old male, he is single, and he lives in Mataas na Kahoy, Batangas City. He is a former freshmen engineering student in one of the universities in Batangas City. Participant number one has four siblings composed of two females and two males and he is the third offspring in their family. Informant \# 1 was admitted in the hospital from February 12, 2012 to February 25, 2012. He had undergone emergency above knee amputation of left leg due to traumatic vehicular accident.

Informant \# 2 is a 32 years old male, single, from Conde Itaas, Batangas City. He was admitted last August 20 - 25, 2012 in the hospital with a final diagnosis of diabetic gangrene, left foot; type II DM, poorly controlled. He had a family history of non-insulin dependent DM both parents. He stayed with his aunt and uncle since 3rd grade and he was unemployed.

Informant \# 3 is a 43 years old male, married, with three children and all are studying. He lived in Esteban Mayo St. Lipa City. He is currently employed in one of the manufacturers of breakfast cereals and chocolate drink in Batangas City and he works as the production quality controller. He was admitted in the hospital last April 4 - 14, 2010 due to vehicular related accident sustaining a mangled right foot and was amputated just below the knee, with lacerated wound on left eyebrow, and multiple abrasions on face, right forearms and left leg.

Informant \# 4 was a 51year old female, widowed, with three children. Her eldest son and her second children are the bread winner of the family. She lives in P. Torres Lipa City, Batangas. She was admitted last January 28, 2013 to February 8, 2013, and she was diagnosed with buerger's disease left foot and underwent above knee amputation. She was diagnosed as hypertensive at age 40's. She confirmed that ten months prior to admission she had undergone ungiectomy of left toes. However, she noted an ulcer like lesion on the operative site, nonhealing, mildly painful. Then three months before admission she developed small dark colored lesions on left leg and foot, with negative signs of fever, but with pain on ambulation. Then one month prior to admission there is an increase in size of left leg wound, now with associated pain that is severe enough that she had been having difficulty of sleeping. There is a progressive increase in pain sensitivity, consulted and was admitted.

\section{Sampling Technique}

The researcher utilized the purposive sampling technique in selecting the informants of this case study. In this technique the researcher sets down the characteristics used in choosing the informants. The informants of the case study were the four participants who had undergone lower limb amputation among hospitals in Lipa City, Batangas over a six months post- 
operative duration in the year 2009 - 2013. Creswell (2009), Teddlie (2009), Holloway (2010), \& Gupta (2011) explained that purposive sampling does not produce a sample that is representative of a larger population, but it can be exactly what is needed for cases- study of organization, community, or some other clearly defined and relatively limited group.

\section{Instrumentation}

The study used an unstructured interview questionnaire and there are no prearranged guide questions allowing the researcher to have spontaneity and develop questions while interview. The unstructured questions provide the interviewer to build a better rapport towards the interviewee due to its parallels with a normal conversation, and it gain more honest response from the interviewee. The thrust of the interview is on the general condition of the participants. All the primary data from the results of the one-on-one interview are recorded in a voice and video recorder per participant's given consents. All voice and text messages, electronic mails (E-mails), and personal chat from social network (Facebook) are recorded for additional references. The researcher includes the collection of medical history or profile from participant's hospital medical records as the secondary data.

\section{Data - Gathering Procedures}

For the researcher to obtain the data a written request letter was sent to the President and Medical director of the hospital thru the nursing service director and the chief of medical records. The researcher waited and followed-up for the approval in relation to the request to have an access in the hospital medical records of the patients. Once approved to have the access in the hospital data bank, the researcher conducted the identification of patients who undergone amputation. Identified participants were given a consent letter that will allow the researcher to conduct one-on-one interview and include the participants hospital medical records in this case study. During the interview of participants, the researcher used unstructured questionnaire. The interview focused on the general conditions of the informants. Written all verbal and nonverbal reactions showed by the interviewee. The next step is in the medical records and the operating room department for the detailed medical history or profile information of the patients. Then, recording and transcription of verbalized conversation and written information are kept confidential. All the primary data from the results of the one-on-one interview are recorded in a voice and video recorder per participant's consent. All text messages, electronicmails (E-mails) and personal chat from social network (Facebook) are recorded for additional 
references. The researcher included the collection of medical history or profile from participant's hospital medical records as the secondary data. The medical profiles of the participants were also used by the researcher in validating primary data related to participant's hospitalization. Then all the data collected were processed and analyzed according to the identified significant scenario and follow through the process of identifying the life experiences. Through this procedure, essential topic emerged following the appropriate creative analytic process interpretation and analysis of data gathered.

\section{RESULTS}

Challenges Encountered by the Amputees

Physical Challenges

Mobility problem.

It is very common to amputees that problems with mobility and immobility arise. Like what informant 1 mentioned during the interview:

"Ahh malungkot kasi wala na isang paa ko tapos hindi ako makalakad kahit pagpunta manlang sa CR eh ang hirap kasi masakit pa yung sugat." (I was sad because I lost my one leg, I cannot even walk going to the restroom, the wound is still fresh and painful).

Activities of daily living are essential routine activities that everybody engages in, which include bathing, toileting, eating, dressing and walking. Functional testing is done in the home subjectively with a checklist performance of task. Patients particularly with functional disability experienced adversity in life. Simplifying the way of living are their daily common goals. Instead of performing other goals the basic task alone becomes a fulfillment for them. A recently developed Self-Neglect Severity Scale, is a validated instrument to measure the person's ability to provide self-care, was designed to be administered in the home setting and that can be compared to subjective task in performing ADL as transpired by Dyer \& Ostwald (2012).

Lack of gait balance.

An amputation can severely affect a patient's balance because their center of gravity will shift towards the remaining leg. This experience is new not only to the amputee's body, but to their mind as well. This functional mobility transition will require strength and re-educate the upper extremities, core muscles and remaining leg to ultimately rebalance the body, which is why 
physical therapy is imperative. The physical and occupational therapists work closely to increase core and leg strength to offset the limb loss (Fitzsimmons, 2011).

Altered physical appearance. People think about how they look and how others look at them. A healthy individual beginning from childhood and throughout life have thoughts and feelings about their body image - their shape, size, and other physical attributes such as hair, teeth, and skin (Gillespie, 2009). According to Houston (2009) and Gillespie (2009), appearance is very important, for it influences individual's good quality of life. Depression and anger are also associated with the imperfect appearance. Houston also studied that when amputees have a negative (bad) body image, they are less apt to be happy with life (Houston, 2009).and it is necessary as part of everyday life. As what informant 2 stated on the interview.

"Tuwing titingin ako sa salamin at nakikita ko yung putol na paa ko nadedepress ako ayaw ko lang ipahalata sa kanila. Iniisip ko ano na magiging itsura ko at paano ako makakalakad pang muli. Ang hirap tanggapin, pero kailangang harapin eh..." (Everytime I look in the mirror and seeing my amputated leg I felt so depressed. I just don't want to be obvious to them. I was thinking what I look like and how I could walk again. It was so hard to accept but to face it!)

Sedentary behavior.

The role of exercise is extremely limited by co-morbidity and disability. Physical activity in the elderly is particularly beneficial: increasing insulin sensitivity; lowering of plasma lipids; reducing blood pressure; increasing bone mineral density; decreasing the risk of hypercoagulability. More importantly, physical exercise has a positive impact on the patient's ability to ambulate, reduces risk of falls, and improves psychological well-being and quality of life. Exercise can be associated with an increased incidence of hypoglycemic episodes especially if the patient is being treated with oral anti-diabetic medications of long duration (Marfella, 2012). Energy is needed purely for survival, performance of ADL and recreational. Unavailability may result to increase fatigability and will demonstrate progressive sedentary behavior over time. Balance with the use of energy may promote mobility to patient with problem in immobility disability and it sustains the energy of the amputee throughout the performance of the daily task and activity (Schrack, 2011).

Phantom pain and Phantom sensation.

Murray (2012) reiterated Gillespie (2009) statement in her study that following amputation, it is very common to experience the sensation that the limb is still present. The brain and the 
nervous system take time to adjust to that new pathway. Often itchy sensations from absent limbs are experienced. To some, these sensations are experienced as pain. The pain can be a tingling, burning, itching or cramping sensation. It is common that painful sharp shooting pains are experienced. These pains may be related to swelling, pressure from prosthesis, muscle spasms, knocking or bumping the limb, temperature, the weather, stress or sometimes they come on for no apparent reason. It is often that these episodes of pain reduce with time, or they can be ignored. It was supported with Pellico (2013), said that two to three months after amputation phantom limb pain can be experience and pain is described as crushed, cramped, or twisted in an abnormal position. According to the study of Bosmans (2010), there are more women than men who are experiencing phantom pain. Analysis shows that more upper limb amputees experience phantom pain than lower limb and phantom pain decreases over time.

"Na depress ako non raul, kasi nga hindi ako makalakad, hindi pa magaling ang sugat ko tapos nararamdaman ko yung kirot nung nawala kong paa. Ganun ba yon parang konektado parin ako?" (I was depressed, because I cannot walk, my stump is not healed yet then I felt pain on my amputated leg. Was it like that? It seems like I am still connected with it?)

\section{Psychological Challenges}

Behavior is learned mostly through observational learning and is taught through modeling. For example, a person could be told the steps to adhere to when performing ambulation or specifically teaching the proper execution of a three-point gait or a swing to/thru, but a demonstration is necessary to show the actual performance of the skill. Modification of behavior involves altering the patient's beliefs regarding the strength of self-efficacy. Interventions serve as the means to facilitate this modified behavior (Unwin, 2009).

\section{Loss of libido.}

People are all sexual beings. This term refers to all the ways that someone expresses loving feelings and emotions. The whole body responds to sexual attraction. Sexuality includes feelings of arousal (expressed by touching, kissing and caressing) as well as sexual intercourse (Jochmann, 2009). Some amputees say that limb loss limits their sexuality. This can be due to a negative body image. It can also be because people fear that they will be rejected by their spouse or partner. It is important that the couple talk together about how the body looks, feels, and works. Talking about this can help prevent misunderstanding or hurt feelings later in life (Houston, 2009). Erectile dysfunction psychological factors such as performance anxiety can contribute to its etiology. Presence of a normal sexual desire but inability to perform due to 
physical limitations can lead to poor quality of life, besides problems of interpersonal relationships, problems with partners and increase in mental stress (Avasthi, 2011). As one of the informants revealed that:

"Hindi ko na maisip yan, hindi na nga tumatayo itong sa akin eh... napansin ko yun nung simulang tumaas ang blood sugar ko. Dati sa isip ko kaya ko pa magmahal. Pero hindi na ngayon sino pa magkakagusto sa akin eh alagain na ako, at saka hindi ko na kayang ibigay pa sa kanya ang magiging pangangailangan niyang sexual kung sakali man na nagka asawa ako. Kaya tiis lang kung sakaling makakaramdam pa ... (pa ilingiling ng ulo) " (It doesn't come to my mind to think about that, my pennis doesn't even erect... I had noticed this since my blood sugar goes up. Before I thought I could still love someone, but not anymore, whom you think would like to love someone who will be a burden for them, and I can't even give her whatever she needs sexually if ever I got marry. Total abstinence if ever I feel... (shaking his head)

Involved suicidal tendency.

There was a time when one of the informants felt hopeless and he attempted suicide by strangulating his neck, though it was not successful because the hook where he will tie the rope was too high to reach. This was noticed by his uncle then later removed all the stuff that he could use for another attempt of suicide.

"Sa una mabigat, siguro mga 3 months na wala akong gana kumain, nagtititig lang ako sa bintana ng kwarto ko, laging umiiyak sa madaling araw pag tila tulog na sila auntie mel... May oras din na gusto ko nang wakasan ang buhay ko kaya lang hindi ko maabot yung lubid na itatali ko sana sa window. " (at first it was so hard I lost my appetite for about 3 months, I stared at the window of my room, cried during midnight when everyone is asleep... There was a time when I wanted to end my life by strangulating my neck, the hook where I will tie my rope was too high to reach then my attempt failed.)

Self-pity brought about by negative image deformity.

as one of the informants verbalized: When there is a family gathering, he joined with them. Sometimes he pitied himself because he doesn't want to be fully dependent. He seldom mingles with his friend with the reason that he feels indifferent to them. He wanted to be normal and independent though reality proved that he needed somebody to depend on.

"Well..." (looking down on his feet and shook his head) "wala akong magawa kahit naaawa ako sa sarili at naiinggit sa iba na kumpleto ang paa eh hinahayaan ko nalang lumipas, hinga ng malalim nagiisip ng masayang bagay gaya ng tumama sa lotto. Tapos nawawala narin. Kasi kung iiyak lang ako ng iiyak wala rin mangyayari eh." (Well..., I don't have anything to do away against it but to let it pass, I pity myself, comparing my disability to other normal people. I just think of happy thoughts like winning in the lottery. For me crying will not solve the problem.) 
Depression and Substance abuse.

One informant expressed his struggles in life is looking at the mirror everyday with the thought that he saw his life full of regrets. He even attempted suicide through swallowing 5 pieces of unknowned pills out of his depression, thinking that ending his life is the answer to his depressive thoughts (he stared at the window and paused with a deep thought). This resulted to dizziness and headache. He said he wanted to sleep and not to wakeup anymore. He also believed that everything had change in his life. He stopped schooling, he brokeup with his sweetheart. He is thinking that it will be hard for him to find a better job in the future though he never tried. He is fully dependent on his parents and siblings.

"Ipinaliwanag sa akin sa ospital kasi durog-durog daw ang mga buto sabi ng doktor at hindi kakayanin ng bakal na pagdugtungin ulit kaya dapat daw na putulin. Kung meron lang pwedeng gawing iba pa wag lang putulin ang paa ko baka hindi ako pumayag na ipaputol kaya lang wala na raw pwedeng remedyo eh. Natakot din ako nung una pero inasure ako na hindi raw masakit, sa loob ko hindi nga masakit pero wala na akong isang paa. Kaya nga nung iniskedyul na ako hindi na ako pala kibo kasi kung may magagawa lang ako sana hindi ko na ipinaputol. Hindi ko nalang ipinakita na umiiyak ako pero lungkot na lungkot ako kasi ewan ko parang nawawala na kalasingan ko nun. Nagkahalo halo na ang nararamdaman ko. Buti nalang nung hinawakan ng ama ko yung kamay ko at sinabi niya hayaan mo anak makakalakad ka parin. Hayun medyo nawala yung pangamba ko na baka tuluyan nalang akong maging lumpo." (according to my surgeon they cannot fix my leg and replace it with metal plates because the whole limb is severely damage and it require amputation. If only I could have a choice to avoid the surgery, then I would, but since I don't have a choice then I'll accept it. I was scared at first though they said that I will not feel the surgical procedure and still I will be losing my leg. When I was scheduled for the operation, I didn't talk to them and deep inside me I'm tearful and sad. My feeling and emotion were mixed up with fear, good my father is there for me and assures me that I can walk again and do not worry that I will not be a lame forever)

"Nakakita ako ng mga gamot sa bahay hindi ko lang matandaan kung anong gamot yun mga limang piraso ininum ko sabay sabay, akala ko paglalamayan na ako non pero nahilo lang ako, Nakaka depressed ang mga pangyayari. Ayaw kong kumain gusto ko matulog lang, at di na magising. Ang pangit ng pakiramdam imagine lahat sa buhay ko nabago. Naapektuhan ang pag aaral ko, nawala ang sweetheart ko, tapos hindi ko alam kung makakatrabaho pa ako. O magiging pakainin nalang ako ng mga magulang at mga kapatid ko." (I saw a couple of drugs in my house maybe its 5 pieces then out of my depression I swallowed the medicine at once thinking that it is the end of my life but, I just got dizzy and have a headache. I wanted to sleep and not to wake up anymore. I was so crazy everything changes in my life. I stop schooling, my sweetheart broke me up, I don't know if I could find a decent job. Or I will be a parasite and fully dependent to my parents and siblings...) 


\section{Emotional Challenges}

Close relationship.

One of the amputees narrated that at home it was his parents who took care of his stump. With the help of his cousin which is a nurse she helped him clean the stump with povidone iodine and change the dressing daily after her duty from another hospital. She also monitored if he took the medicines every day at the right time.

"Well parang normal parin yun nga lang bawas na ang paa at nadagdagan ng sagabal na saklay, pero kailangan eh. Bihira narin ako makisama sa mga barkada ko. Dito naman pag lakad pamilya kasama naman ako pero hindi naman ako makabitbitng mga dala ng kasama ko. Minsan nga naiinis na ako kasi ako pa ang inaalala nila at ina alalayan." "Gusto ko ring mapatunayan sa kanila na kaya konang mag isa, pero minsan talaga kailangan ko parin ng tulong nila eh" (im still normal, just maybe I had lost one of my leg and using this crutches kept me disturbed, but since I needed it I had to. I seldom mingled with my friends. When we had a family affair yes, I go but I can't keep them though, sometimes I was pissed off because they cared too much.) (I wanted to prove to them that I can be independent but still sometimes I still really need their help)

Hopelessness or helplessness and does not see a future.

He said that it was the first three months after amputation was the saddest part of his life. $\mathrm{He}$ had lost his appetite and he usually stared at the window of his room and cried almost everynight when all are asleep. There was a time when he felt hopeless and he attempted suicide by strangulating his neck, though it was not successful because the hook where he will tie the rope was too high to reach. He wanted to be independent, but his disability limited him because he had mobility problem. He wanted to help with the household chores, but he is incapable of doing so and it's the reason why he thought and felt useless.

"well taga hugas manlang ng plato dito sa bahay. Or taga bukas manlang ng pinto pagmay dumarating, o kung makakalakad lang ako eh makapagtrabaho din ako at maintrega sa kanila ang sweldo ko. Alam mo yun feeling ko eh wala akong silbi dito sa kanila. Pero hindi ko narinig ni isang sumbat sa kanila sa halip eh full of encouragement ang naririnig ko". (at least I can wash the dishes, or even get the door when someone came. Or if I could only walk, I will work so that I can contribute my salary to them. Because I felt I'm useless for them. But you know what I didn't hear any complaint from them instead full of encouraging words is what they utter...)

\section{Socio-Economic Challenges}

Development of anti-social and dissociative behavior

(few friends/lives alone, withdrawing from friends). One informant tried to go alone outside, but he was so paranoid with the thought that everyone is looking at him and he is the center of attention. He had a negative attitude towards what other people might think against him and 
this prompted him to stay in the house and be alone. Learning his situation that everyone is free to think and what other people think against him will not affect his being.

“Oo, pero nahirapan ako nakakailang kasi pinagtitinginan ako ng tao. Naiisip ko tuloy na sikat ba ako? artista ba ako (hehehe). O hinuhusgahan na nila ako sa isip nila at pinandidirihan o kinaaawaan. Ang hirap pero nasanay narin ako katagalan siguro mga anim na buwan din yun bago ako naka adjust, kasi hindi ko naman mabasa ang mga nasa utak nila bahala na sila mag isip."(Yah, but I got paranoid with the feeling that everyone is looking at and I don't want to be the center of their attention. I was thinking if I am a celebrity (laughed)... or they are judging me or maybe obnoxious or someone to pitty of. But it took a longer period before I got used to it maybe six months. I just said to myself, since I cannot read what is in their mind so it's up to them, they are free to think.,.)

Fear of losing a job.

Though he said his life turned positively he still have this fear with him he does not know if his family could survive this. He is even worried with his physical appearance losing one of his legs. For him it creates a big impact not only for him but for the whole family as well. He saw himself as a lame person who is fully dependent. He also worried to lose his job. He feared that his wound might got worse and he will not be able to walk again.

"nag subok ako nag hanap ako sa internet pero nang malaman nila na disabled ako eh hindi na nila ako tinanggap. Feeling ko nga discriminated kaming PWD pero sabi nila kasi daw ang job description ay baka mahirapan daw kami. Kaya ayun sabi nalang eh maghintay nang tawag nila." (I tried looking for a job in the internet and I was turned down when they realized that I was disabled. I felt discriminated though they reiterated to me about the job description that I will have difficulties based on the nature of my work. Then they just tell me to wait for their call).

Problem with money.

The surgical procedure alone is costly including the treatment and rehabilitation. Added with the prosthetics and devices for handicapped and aids to be used after recovery and to be able to walk again. One of the informants revealed that he was not able to attend therapy because of lack of finances and wearing prosthesis is so expensive. He used custom made crutches by his father.

"Ay hindi na kasi wala naman daw akong isusuot na pekeng paa." (I didn't go for a therapy because I will not wear a fake leg.) "Oo prosthesis at mahal daw yun eh. Pati mag pa therapy." (Yah, prosthesis and this is expensive even the therapy...)

Fear of rejection.

Living with the fear of rejection can be quite detrimental to our quality of life as it tends to impact and influence many aspects of our everyday experience. Fear can be conquered without drugs by digging down the source and replacing negative associations with positive ones. 
Informant's hold back their opinions about certain things because they fear that other people might disapprove or disagree.

\section{Spiritual Challenges}

Involved loss of faith.

For him spirituality provides an essential care, enriching experience, and a reason to live. To him prayer represents a way to connect with a supreme spiritual being and it activated his spiritual energy, which he can reveal himself in everyday life. Yes, he had revealed himself as a sinner and he kept on thanking God for extending his life. Before he attended church services but because of his condition he had a hard time going to church. His spirituality goes the lowestlowest of his life and now he is working out to uplift himself spiritually. He said with the grace of God he can do all the good things in life. He doesn't forget to pray but sometimes for him his prayer is not enough. He believed that prayers gave him the power to survive. He added that:

"Noon kasi, gusto ko naman sana mag simba kaya lang napa barkada ako tapos ang bisyo hindi maiwasan kaya ang hirap lumapit sa panginoon. Lalo pa hindi ako makasimba mag isa. Kaya natatamad narin ako ngayon. Siguro kung kumpleto pa paa ko baka maala ko mag simba." (Before, I wanted to go to church but because of my friends I cannot even avoid my vices and it was so hard to get close to God. The more I cannot go alone to church. That is why I am also so adamant to go to church. Maybe if my legs are still complete, I would remember to go to church!)

\section{Coping mechanism}

People with limb loss may use mobility aids such as wheelchairs, scooters, crutches or canes.

Such equipment should be considered a part of their personal space. Grabbing an arm or crutch could cause unbalance; pushing or pulling a wheelchair unexpectedly could upset the person or even damage the device. To the casual observer, these forms of equipment may be considered just that - a piece of equipment. But to people whose mobility depends on it, the equipment is part of who they are.

An amputee should learn new ways to do things they enjoyed before. Cleverness and creativity are needed in finding ways to enjoy. Amputee should not be self-limiting to the label of "disabled". The focus should no longer be on what is gone, but on the future. Learning to be comfortable with the use of prosthesis will likely change the body image.

Coping with the physical challenges these varied between informants. What are common among informants are the strong family supports that provided informants easy way of coping 
psychologically, emotionally, socio-economically and spiritually. Coping with challenges are summarized as the following:

Physical coping.

achieved through practise and mastery of gait and balance, proper practise in using assistive devices and hastened adjustment to the new body. Wearing of prosthesis improved physical appearance and concealed deformity as it became part of the body. Promoting mobility elicits a sedentary behavior and lifestyle among informants. Phantom pain is managed with pain medication and proper care of the stump avoiding alcohol base cleanser that promotes dryness of skin, or too much skin softenner. This helped amputees maintain a good skin turgor and prevented infections or swelling.

Psychological coping.

sensitivity of family members to informant behavior and needs prevented occurrence of suicide, depression and self-pity.

Emotional coping.

informants coped emotionally with the help and support from the family, relatives, friends and the community they lived with. Through their pressence and availability for amputee projecting a caring, non-judgemental attitude and building trust. Showed dignity and respect to amputee and empathized with them.

Socio-economic.

Informants encountered range of barriers in attempt to access health care. Limited availability of services and prohibitive costs of care and equipment needed for rehabilitation hinder the informant access to health care. The support group (family, friends, employer, government and non-government organizations linkages) had showed the greatest factor in coping with this aspect and they posed as the best alliance of the informants. Full independence is achieved when the informants had back to the reality of life. 
Spiritual coping.

regaining mobility increases self-efficacy of the informants and it helped established informant's trust relationship to the divine power and expands consciousness to meet the challenges and coping skills.

\section{DISCUSSION}

In a qualitative research to develop a comprehensive understanding of a phenomena it uses multiple methods or data sources which is referred by the researcher as triangulation. It is also used to validate the convergence of the information gathered from different sources. To deepen and widen researcher's understanding.

Denzin (1978) and Patton (1999) identified four types of triangulation:

1. method triangulation

2. investigator triangulation,

3. theory triangulation, and

4. data source triangulation.

Methodological triangulation was utilized by the researcher that involves using more than one option to gather data, such as interviews, observations, questionnaires, and documents. The researcher includes interview from relatives, love ones, and significant others. Which support the reliability of the data thru the interview expressing their thought and feelings towards the amputee's, and the disabilities itself. They reiterate their role in providing care for the amputee's and identify that there is a need to increase family awareness in anticipating the needs of the amputees. Likewise, full support must be given to them. Health education campaign may be formulated by the local health leaders and provision of assistive devices and equipment to achieve the equalization and opportunities for persons with disabilities may also be done. Future research needs to explore more about persons with disabilities related to amputee's physical, psychological, social/economic, emotional, and spiritual aspect of life.

\section{Conclusion}

Amputation of the limbs can cause substantial changes on physical, psychological, emotional, social/economic, and spiritual aspects of the life of an amputee. Strong support from the family, friends, and community help the amputee in coping with sudden changes of the quality of life, and resilience during periods of stress and life transition. Spirituality provides a big role in the life of an amputee. Providing essential care, enriching experience, and provide a reason to live for many amputees. Having a connection to the Supreme spiritual being it activates spiritual 
energy and can reveal itself in everyday life. Positive and an optimistic attitude helped the informants to improve the quality of life. Redirection of skills of the informants can lead to productivity, enhancement of knowledge and achievement of self-worth.

\section{REFERENCES}

Avasthi Ajit1, S. G. (2011). Erectile dysfunction in diabetes mellitus contributes to poor quality of life. International Review of Psychiatry; 23 (1):93-99. Chandigarh: India.

Bosmans, J., Geertzen, J., Post, W., Van der Schans, C., \& Dijkstra, P. (2010). Clinical Rehabilitation, Vol. 24 issue 5,. Clinical Rehabilitation, p.444-453. 10p. 1 Diagram, 4Charts, 1 Graph.

Burger, H., \& Marincek, C. (2007). Disability and Rehabilitation. Research, systematic review, tables/charts.

Cordova Cynthia M. (2011). The Lived Experience of Spirituality Among Type 2 Diabetes Mellitus Patients with Macrovascular and/or Microvascular Complications. The Catholic University of America, 205, ISBN: 978-1-1124-64612-1.

Creswell, J. (2009). Research Design: Qualitative, quantitative, and mixed methods approaches. California USA: Sage Publication.

Day, A. (2011). Mortality rate and predictive factors in patients who undergo lower-limb amputations while hospitalized for other reasons. 165.

Denzin, N. ((1978). Sociological methods: A). Sociological methods: A sourcebook. New York, NY: Mc Graw-Hill.

Donatelle, R. (2012). Spiritual Health, Access to Health, 12 ed. San Francisco California: Pearson Education Inc/ 94111, pp.34.

Dyer, C., \& Ostwald, S. (2012). Managing Disability. Washington D.C.: Academic Press. p 87.

Finkel, M. (2011). Public Health in the 21st century. Vol. 1. Global issues in public health, 183.

Fitzsimmons, A. (2011). Mobility After Amputation. Mobility Management, Consumer Edition April 2011 issue.

Gillespie Jamie. (2009). Below the knee amputee HPC Registered Prosthetist/Orthotist Pace Rehabilitation. Diambil kembali dari http://pacerehab.com/files/Life after Amputation Surgery 
Gondo, G. (2013). Life After Amputation. In Motion Journal Volume 23, Issue 1 January/February 2013.

Graham, K. Z. (2008). Estimating the Prevalence of Limb Loss in the United States - 20052050. Archives of Physical Medicine and Rehabilitation, 422-429.

Gupta, S. (2011). Workshop on Research Methodology. New Delhi, India: Centrum Press, pp85-198.

Hamilton, I. S. (2012). An intro to gerontology, aeging and managing co-morbidity and disability. New York: Cambridge University Press.p94.

Holloway, I., \& Wheeler, S. (2010). Qualitative Research in Nursing \& Healthcare, 3rd ed. United Kingdom: Wiley-Blackwell Publishing.

Houston Sandra. (2009). Our Body Image, Relationship and Sexuality. Amputee-Coalition First step. University of Central Florida, USA.

Jochmann Carmen. (2009). The Benefits of human touch. Diambil kembali dari http://suite101.com/carmenjochmann

Marfella R. Paolisso. (2012). Antidiabetic Drugs for Elderly: pp475-478. Naples, Italy.

Murray Gail. (2012). Phantom limb pain,. Royal Berkshire Journal. National Health Service, United Kingdom, July 2012 issue.

National Council on Dissability Affairs. (2013, May 5). Diambil kembali dari http://www.ncda.gov.ph/downloadable-

forms/table9.disabledpersonsbytypeofdisability.sexandagegroup:2000

O'Reilly DJ, F. X. (2011). Estimation of the impact of diabetes related complications on health utilities for patients with DM2.

Patton, M. ((1999)). Enhancing the quality and credibility of qualitative analysis. Health Science Research, 34, 1189-1208.

Pellico L.H. (2013). Medical Surgical Nursing. Philidelphia PA 9103: Lippincott Williams \& Wilkins .

Perrin, K., Sheenan, C., \& Potter ML, K. M. (2012). Pallative Care Nursing, Caring for suffering patients. Jones \& Barlett Learning, pp.163-185.

Santy, J. (2009). Orthopaedic and Trauma Nursing 2nd Ed. Churchill Livingstone.

Schrack, J. A. (2011). Aging and the conservation of energy. The John Hopkins University, pp145. ISBN: 978-1-124-76138-1.

Senra Hugo, R. A. (2011). Beyond the body image: a qualitative study on how adults experience lower limb amputation. sagepub.co.uk/journalspermissions.nav. 
Teddlie, C., \& Tashakkori, A. (2009). Foundations of Mixed Methods Research. California: Sage Publications, 91320, p25.

Unwin Jennifer. (2009). A Prospective study of positive adjustment to lower limb amputation. Clinical Rehabilitation. Sage Publication Ltd. Hull UK, 1044-1050.

Yin, R. (2009). Case Study Research: Design \& Methods 4th ed. California USA: Sage Publishing, pp 16-59. 